\title{
RANKING OF LEAN TOOLS USING WEIGHTED SCORING METHOD
}

\section{S. MUTHU BASKARAN}

Assistant Professor, AMET University, Chennai, Tamil Nadu, India

\begin{abstract}
Lean Manufacturing is a manufacturing paradigm, when implemented, it gives an evolutionary change in the production environment. The selection of lean tools is the changing factor in implementing the lean strategy. Lean tools can be selected by prioritizing the lean tools depending on its ability to attack lean wastes. Lean wastes affect any production process. It is required to find the lean wastes at the earliest. This study was conducted in the steering knuckle manufacturing section of a manufacturing industry to identify the lean wastes in the production line. Lean wastes-Lean tools relationship matrix was developed to find the priority among the lean tools. The ranking method using weighted scoring method showed a new way of selecting the lean tools among the various options. It also provides a systematic procedure for the managers to select the right lean tools to reduce lean wastes.
\end{abstract}

KEYWORDS: Lean Wastes, Lean Tools, Ranking \& Weighted Scoring Method

Received: Dec 15, 2017; Accepted: Jan 05, 2018; Published: Feb 05, 2018; Paper Id.: IJMPERDFEB2018131

\section{INTRODUCTION}

This project addresses the application of lean manufacturing concepts to the continuous production process sector with a focus on the manufacturing industry. The primary objective of lean manufacturing is to assist manufacturers who have a desire to improve their company's operations and become more competitive through the implementation of different lean manufacturing tools and techniques. The term "lean" as Womack et.al (1990) define it as a system that utilizes less, in terms of all inputs, to create the same outputs as those created by a traditional mass production system, while contributing increased varieties for the end customer. Lean is to manufacture only what is needed by the customer, when it is needed and in the quantities ordered. The basic ideas behind the lean manufacturing system, which have been practiced for many years in Japan, are waste elimination, cost reduction, and employee empowerment. Hines and Rich (1997) put forward seven kinds of value stream tools and tried to select tools from the perspective of reducing waste, which became the basis for value stream map decisions. Quickly following the lean's success in Japan, other companies and industries, particularly in the US, copied this remarkable system, then it becomes the world's leading strategy.

\section{LITERATURE REVIEW}

"Lean" focuses on abolishing or reducing waste (or "muda", the Japanese word for waste) and on maximizing or fully utilizing activities that add value from the customer's perspective. From the customer's perspective, value is equivalent to anything that the customer is willing to pay for in a product or the service that follows. The seven types of wastes are Inventory, Overproduction, Over processing, Defects, Motion, Transportation and Waiting. Karlsson and Ahlstrom (1996) utilized a set of measures and presented in a form of checklist to assess the extent of leanness. In this paper, a self assessment model was developed using questionnaire tool in a five-point scale to rate the level of lean tools in a machining line of a steering knuckle manufacturing 
industry. The objective is to systematically demonstrate, how lean manufacturing tools when used appropriately can help the process industry to eliminate the lean wastes and to improve their journey towards leanness. The organization of this paper comprises of Lean wastes, Lean Tools ranking, Lean Tools-Lean Wastes Relationship matrix, Weighted Scoring Model and Prioritization of Lean Tools, Results and Discussion and Conclusion.

\section{LEAN WASTES}

The lean wastes or non-value added activities or Muda bring a lot of attention from the management. Nowadays, the management is not ready to leave a single waste affecting its business. Lean wastes create a stagnation of resources, wastage of human effort and money. If a process is hindered by lean wastes, it reduces the throughput rate and causes unevenness and overburden of job. Such a fluctuation in process affects the entire supply chain. The description of seven lean wastes is tabulated. Among the seven lean wastes over production is highly dangerous as it causes 3M. Muda, Mura and Muri. Muda means non-value added activity, Mura means over burden and Muri means unevenness. The seven lean wastes were listed by Taichii Ohno of Toyota Production system. Lean wastes consume the effort of entire production unit and leave a huge loss to the organization. To have a smooth flow of production process, lean wastes should be identified, measured and eliminated. Otherwise the industry must face the consequences of paying huge penalty for the waste creation and accumulation. The waste elimination is the prime goal of any lean system. In short, lean strategy stands for action against lean waste.

Table 1: The Lean Wastes and their Description

\begin{tabular}{|l|l|l|}
\hline Wastes Code & \multicolumn{1}{|c|}{$\begin{array}{c}\text { Types of } \\
\text { Wastes }\end{array}$} & \multicolumn{1}{c|}{ Description } \\
\hline W1 & Over production & Producing more than the customer requirements \\
\hline W2 & Over processing & Processing the component more than the necessary \\
\hline W3 & Inventory & Keeping storage of goods as safety stocks \\
\hline W4 & Motion & Any movement of an employee within the premises \\
\hline W5 & Transportation & Movement of goods within or outside the shop floor \\
\hline W6 & Defects & Non Confirmation to the requirement \\
\hline W7 & Waiting & Waiting for an operator or a machine \\
\hline
\end{tabular}

Case study industry is a steering knuckle manufacturer who wanted to implement lean manufacturing in the shop floor. Lean tools are meant to affect the lean wastes. So, it is necessary to find the pulse of lean wastes to understand the current situation prevailed in the plant. Finding the \% of Lean waste is not only exposing the non-value added activity in the plant but also gives a chance to find the right solution in terms of lean strategy.

Table 2: The Lean Wastes and their Percentage

\begin{tabular}{|c|l|l|c|c|}
\hline Sl. No & Wastes Code & Types of Wastes & \% of wastes & Out of 1 \\
\hline 1 & W1 & Over production & 14 & 0.14 \\
\hline 2 & W2 & Over processing & 6 & 0.06 \\
\hline 3 & W3 & Inventory & 14 & 0.14 \\
\hline 4 & W4 & Motion & 21 & 0.21 \\
\hline 5 & W5 & Transportation & 30 & 0.30 \\
\hline 6 & W6 & Defects & 5 & 0.05 \\
\hline 7 & W7 & Waiting & 10 & 0.10 \\
\hline
\end{tabular}




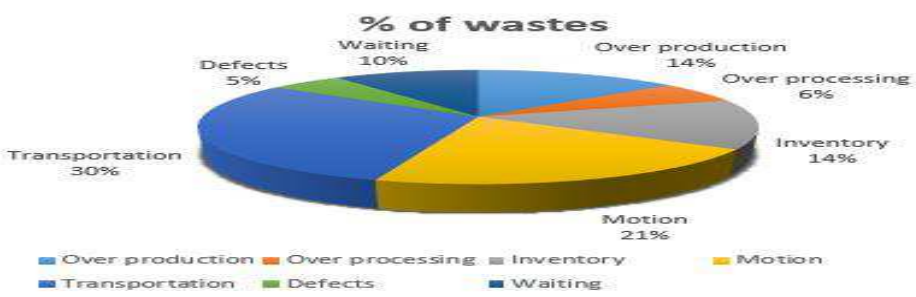

Figure 1: Bar Graph Showing the \% of Lean Wastes

\section{LEAN TOOLS RANKING}

Lean tools affect the performance measures and this was surveyed by several researchers worldwide. Seyed Mohammad Hossein Hojjati et al. (2013) in his paper explained the ranking of 13 lean tools by an integrated SAW, TOPSIS and Borda method. Wan, H-d., Sahasrabudhe (2014) employed ANP method in prioritizing the lean tool selection based on the urgency of current state of the firm. E. Roghanian et al. (2014). proposed a methodology combining the application of QFD in fuzzy environment with PROMOTHEE in ranking of lean enablers. Amin, Md Al \& Karim, M.A. (2013) proposed a quantitative methodology was developed to evaluate the contribution of selected lean strategies to reduce manufacturing wastes within the time constraints. Alireza Anvari et al. (2014) applied a modified VIKOR method in lean tools selection. In this research work, a MCDM approach was followed to find the waste eliminating capability of lean tools.

Table 3: Showing the Lean tools and Description

\begin{tabular}{|c|l|l|}
\hline Lean Tools & \multicolumn{1}{|c|}{ Lean Tools } & \multicolumn{1}{c|}{ Description } \\
\hline T1 & 5-S & House Keeping tool. \\
\hline T2 & Quality Process & Finding the good products from total products produced. \\
\hline T3 & $\begin{array}{l}\text { Work Cells / } \\
\text { PC's }\end{array}$ & Managing the work cell for easy accessibility \\
\hline T4 & Line Balancing & Balancing of operators work and operation. \\
\hline T5 & Standard Work & Documentation of work in a standard way. \\
\hline T6 & Quick Changeovers & Set up time reduction techniques. \\
\hline T7 & TPM & Maintain the equipment effectively. \\
\hline T8 & Continuous Flow & $\begin{array}{l}\text { Create ideal condition for flow by reducing the work in } \\
\text { process inventory. }\end{array}$ \\
\hline T9 & Pull Systems & $\begin{array}{l}\text { Let the downstream process to pull the product by using } \\
\text { Kanban cards. }\end{array}$ \\
\hline T10 & Levelling & Levelling the product volume and variety \\
\hline T11 & Training & Employees have training on lean implementation. \\
\hline T12 & $\begin{array}{l}\text { Supplier / Customer } \\
\text { Alliances }\end{array}$ & Supplier and customer support on lean practices. \\
\hline
\end{tabular}

\section{LEAN TOOLS-LEAN WASTES RELATIONSHIP MATRIX}

Lean tools can affect the lean wastes. After finding the lean wastes in the manufacturing industry, lean tools were selected to reduce the lean wastes or Muda. Industry was successful in relating the waste eliminating process with lean tools. This relationship was tabulated in the lean tools-wastes matrix. A five-point scale is used to relate the level of lean tools in reducing the lean wastes. With the help of lean expert's opinion, a relationship between lean wastes and lean tools were plotted in a five-point scale. The journals proposed by several authors are the proof that lean tools can be the change agent in lean transformation. By implementing lean tools in a systematic manner industries can witness a real change. 


\section{WEIGHTED SCORING METHOD}

Weighted Scoring method is a Multi-Criteria Decision Making method used to find the relationship between the criteria and the alternatives. In this method, the weights of criteria are multiplied with the values of alternatives and the weighted sum indicates the overall sum of process. In this research work, the following steps have been followed to calculate the overall sum and interpret those values for finding the priority of lean tools and assessment.

Step1: Find the weights of lean wastes using the mathematical formulation given in the Lean wastes formulation. Weights $=\mathrm{W}_{\mathrm{i} \text { in }} \%$, Here $\%$ of wastes is taken as weights.

Where $\mathrm{i}=$ no. Of lean wastes, $\mathrm{i}=1,2,3,4 \ldots \mathrm{n}$,

Step 2: Find the level of lean tools in reducing the lean wastes with the help of lean experts in a 5-point scale. Level of Lean tools $=t_{j}$, Where $j=$ no. Of lean tools, $j=1,2,3,4 \ldots n$

Level of Relationship $t_{\mathrm{j}}$ is given by $1=$ Very low, $2=$ Low, $3=$ Medium $4=$ High, $5=$ Very High.

This relationship was drafted once the lean wastes were identified.

Level of Relationship showed the details of marks given for five-point scale for each of the wastes against the lean tools. The level of lean tool is rated against each of the lean wastes. If the lean tool is rated as 5, then it shows higher level of impact on a lean waste. If it is rated as 1 then it shows the level of lean impact is very low on a lean waste.

Step 3: Multiply the weights of lean wastes by level of relationship of lean tools to find the overall sum for each tool as well as the overall sum of all the tools.

$$
\text { Leanassessnent }(L i)=\sum w_{i}^{*} t_{j}
$$

Step 4: Interpret the results to find the priority of lean tools.

Table 4: The Cross Tabulation of Lean Tools and Lean Wastes

\begin{tabular}{|c|c|c|c|c|c|c|c|c|c|c|c|c|c|}
\hline Lean Wastes & \multicolumn{10}{|c|}{ Lean Tools } \\
\hline \multicolumn{2}{|c|}{ Weights } & T1 & T2 & T3 & T4 & T5 & T6 & T7 & T8 & T9 & T10 & T11 & T12 \\
\hline W1 & 0.14 & 3 & 2 & 4 & 2 & 5 & 2 & 3 & 5 & 5 & 5 & 2 & 4 \\
\hline W2 & 0.06 & 1 & 5 & 1 & 1 & 5 & 2 & 3 & 5 & 5 & 4 & 2 & 2 \\
\hline W3 & 0.14 & 3 & 3 & 4 & 3 & 5 & 5 & 4 & 5 & 5 & 5 & 2 & 3 \\
\hline W4 & 0.21 & 3 & 1 & 5 & 5 & 5 & 1 & 3 & 3 & 1 & 1 & 1 & 1 \\
\hline W5 & 0.30 & 4 & 1 & 5 & 5 & 5 & 1 & 3 & 1 & 1 & 1 & 1 & 2 \\
\hline W6 & 0.05 & 1 & 5 & 1 & 1 & 5 & 1 & 5 & 1 & 1 & 1 & 1 & 1 \\
\hline W7 & 0.10 & 4 & 2 & 5 & 3 & 4 & 4 & 4 & 5 & 5 & 5 & 2 & 3 \\
\hline & & 3. & 2.0 & 4.3 & 3.7 & 4.9 & 2.6 & 3.4 & 3.2 & 2.8 & 2.7 & 1.4 & 2.3 \\
\hline
\end{tabular}

From the above table, it was found that the lean tools were successfully selected for implementation which has major impact in the lean wastes elimination process.

\section{PRIORITIZATION OF LEAN TOOLS}

Lean tools were sorted depending on their capability of affecting the lean wastes. Lean wastes are known to hinder the process flow. So, the proper selection of lean tool is needed to eliminate the lean wastes. Based on the lean 
wastes-Lean tools relationship matrix, the priority of lean tools was listed. The tool got the maximum weighted score stands first in the wastes elimination. The tool which got a low weighted score stands last and so on. The ranking of lean tools based on the weighted score is shown in the table 5 .

Table 5: The Ranks of Lean Tools

\begin{tabular}{|l|l|c|c|}
\hline Lean Tools code & \multicolumn{1}{|c|}{ Lean Tools } & Weighted Sum & Rank \\
\hline T5 & Standard Work & 4.9 & I \\
\hline T3 & Work Cells / PC's & 4.3 & II \\
\hline T4 & Line balancing & 3.7 & III \\
\hline T7 & TPM & 3.4 & IV \\
\hline T1 & 5-S & 3.2 & V \\
\hline T8 & $\begin{array}{l}\text { JIT/Continuous } \\
\text { Flow }\end{array}$ & 3.2 & VI \\
\hline T9 & Pull Systems & 2.8 & VII \\
\hline T10 & Leveling & 2.7 & VIII \\
\hline T6 & $\begin{array}{l}\text { Quick } \\
\text { Changeovers }\end{array}$ & 2.6 & IX \\
\hline T12 & $\begin{array}{l}\text { Supplier/Custom } \\
\text { er Alliances }\end{array}$ & 2.3 & X \\
\hline T2 & Quality Process & 2.0 & XI \\
\hline T11 & Training & 1.4 & XII \\
\hline
\end{tabular}

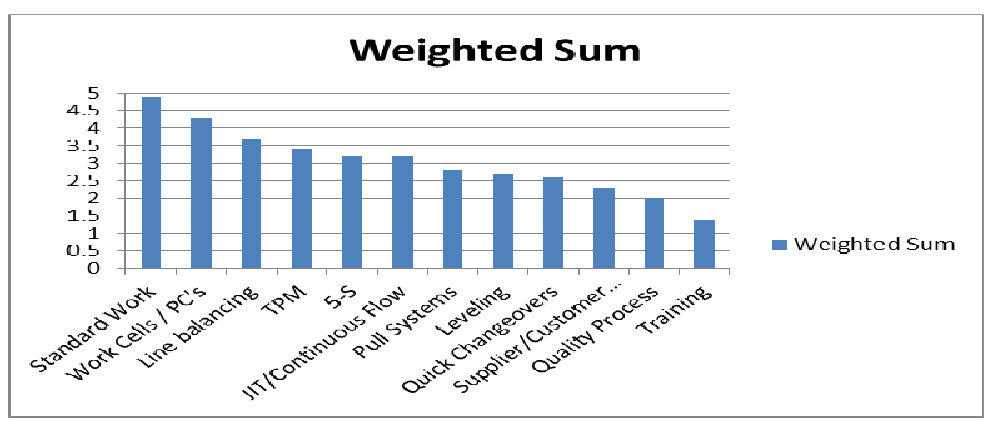

Figure 2: Graph Showing the Ranking of various Lean Tools using the Weighted Sum

\section{CONCLUSIONS}

Lean wastes are notorious to any industry. So, the Lean Wastes were found in a case study industry. Then the most widely used lean tools were selected to rate the lean tools against the lean wastes by using the weighted score model. Prioritization of lean tools using an MCDM is a good attempt in finding the right lean tools for reducing the lean wastes. It also helps the managers in taking right decision on implementing right lean tools.

\section{ACKNOWLEDGMENT}

We acknowledge the case study industry in doing research on lean implementation. We would also like to thank the reviewers for giving valuable suggestions to improve the paper.

\section{REFERENCES}

1. Alireza Anvari \& Norzima Zulkifli \& Omid Arghish, (2014) Application of a modified VIKOR method for decision making problems in lean tool selection Int J Adv Manuf Technol 71:829-841

2. Alsyouf I, Al-Aomar R, Al-Hamed H, Qiu X (2011) A framework for assessing the cost effectiveness of lean tools. Euro J Ind 
Eng 5(2):170-197.

3. Amin, Md Al \& Karim, M.A. (2013) A time-based quantitative approach for selecting lean strategies for manufacturing organizations. International Journal of Production Research, 51(4), pp. 1146-1167.

4. E.Roghanian,Mohammad Alipour, A fuzzy model for achieving lean attributes for competitive advantages development using AHP-QFD-PROMETHEE,J.Ind Eng Int (2014) 10:68.

5. Hines, P., \& Rich, N. (1997). The seven value stream mapping tools. International Journal of Operations and Production Management, 17(1), 46-64.

6. Karlsson, C. and Ahlstrom, P., (1996). Assessing changes towards lean production. International Journal of Operations and Production Management, 16 (2), 24-41.

7. Kuldeep Saini \& Akash Saxena, Online Power System Contingency Screening and Ranking Methods using Radial Basis Neural Networks, International Journal of Electrical and Electronics Engineering Research (IJEEER), Volume 6, Issue 3, May - June 2016, pp. 9-16

8. Seyed Mohammad Hossein Hojjati and Alireza Anvary (2013), “An Integrated SAW, TOPSIS Method for Ranking the Major Lean Practices Based on Four Attributes”, World Applied Sciences Journal 28 (11): 1862-1871.

9. Girish P. Deshmukh, C.R. Patil \& Mona Deshmukh, Lean Techniques in Manufacturing Industry, International Journal of Mechanical and Production Engineering Research and Development (IJMPERD), Volume 4, Issue 5, September - October 2014, pp. 21-26

10. Wan, H-d., Sahasrabudhe, A.M. \& Rivera, L. (2014). Prioritization of lean tools using gap analysis and analytic network process [ANP].Revista $S \& T, 12(28), 9-25$.

11. Womack, J., Jones,D.T. and Roos, D., (1990), “The machine that changed the world," Rawson Associates, NY. 